\title{
PENGARUH KONSENTRASI TEPUNG TEMPE TERHADAP NUTRISI DAN MUTU SENSORI OPAK SINGKONG DARI LOMBOK UTARA
}

\author{
[The Effect of Tempeh Flour Concentration on Nutrition and Sensory Quality of Cassava Opak \\ From North Lombok]
}

\author{
Arindra Pemilia*, Dody Handito dan Yeni Sulastri \\ Fakultas Teknologi Pangan dan Agroindustri, Universitas Mataram \\ *email: arindra.pemilia97@gmail.com
}

Diterima 07 Mei 2019/ Disetujui 10 Oktober 2019

\begin{abstract}
The objective of this research was to determine the right concentration of tempeh flour to enhance nutrition and sensory quality of cassava opak from North Lombok. The method used in this research was Randomized Complete Block Design (RCBD) with six treatments which adding 0\% (PO), 5\% (P1), 10\% (P2), 15\% (P3), 20\% (P4), 25\% (P5) tempeh flour from tapioca starch weight. The data obtained were analyzed by analysis of variance (ANOVA) at 5\% level using SPSS software. If there was any difference, the data tested further by Orthogonal Polynomial Method (OPM) for the nutrient and by Honestly Significant Difference (HSD) for sensory evaluation at 5\% level. The result showed that the tempeh flour concentration gave a significant difference on protein content, fat content, carbohydrate content, total calories, hedonic test (colour and taste) and scoring test (colour, taste and aroma). Based on the result of sensory evaluation, the additional of $15 \%$ of tempeh flour was slightly liked by the panelis and it had protein content 5.92\%; moisture content $4.10 \%$; ash content 2.60\%; fat content 10.89\%; carbohydrate content 76.6\%; total calories 427.63 Cal/100 g; slightly yellow, slightly crunchy; slightly smells tempeh and slightly tastes tempeh.
\end{abstract}

Keywords: Cassava, opak, protein, tempeh flour

\begin{abstract}
ABSTRAK
Tujuan dari penelitian ini adalah untuk menentukan konsentrasi tepung tempe yang tepat untuk meningkatkan nutrisi dan mutu sensori opak singkong dari Lombok Utara. Rancangan yang digunakan dalam penelitian ini adalah Rancangan Acak Kelompok (RAK) dengan 6 taraf perlakuan konsentrasi tepung tempe $0 \%$ (P0), 5\% (P1), 10\% (P2), 15\% (P3), 20\% (P4), 25\% (P5) dari berat tepung tapioka. Data hasil pengamatan diuji dengan analisis keragaman (ANOVA) pada taraf $5 \%$ menggunakan software SPSS, apabila terdapat perbedaan nyata diuji lanjut dengan menggunakan uji Polinomial Ortogonal untuk uji nutrisi dan Beda Nyata Jujur (BNJ) untuk uji sensoris pada taraf $5 \%$. Hasil penelitian menunjukkan bahwa penambahan tepung tempe memberikan pengaruh yang berbeda nyata terhadap kadar protein, kadar lemak, kadar karbohidrat dan total kalori serta uji sensoris hedonik (warna dan rasa) dan uji scoring untuk (warna, rasa dan aroma). Berdasarkan hasil uji sensoris penambahan tepung tempe sebanyak $15 \%$ adalah perlakuan yang cita rasanya agak disukai oleh panelis dengan kadar protein 5,92\%; kadar air 4,10\%; kadar abu 2,60\%; kadar lemak 10,89\%; kadar karbohidrat 76,46\%; total kalori 427,63 Kal/100 g; berwarna putih kekuningan; bertekstur agak renyah; agak beraroma tempe dan agak berasa tempe.
\end{abstract}

Kata Kunci: Opak, protein, singkong, tepung tempe

\section{PENDAHULUAN}

Produksi singkong di Indonesia terus meningkat dan terjadi surplus dari tahun 2015 dan diperkirakan akan terus berlangsung hingga tahun 2020, hal itu dilaporkan oleh Kementrian Pertanian (2016). Data BPS (2014) memperlihatkan bahwa produksi singkong di
Provinsi Nusa Tenggara Barat paling tinggi dihasilkan dari Kabupaten Lombok Utara yaitu sebanyak 23.525,9 ton.

Menurut Zulhaedar dan Nazam (2014), Pengembangan singkong di Kabupaten Lombok Utara NTB memiliki prospek yang cukup baik. Prospek yang ada mendukung peningkatan produksi singkong ke depannya sehingga perlu 
dilakukan pengembangan terhadap produk olahan singkong. Kabupaten Lombok Utara memiliki opak singkong yang khas yakni berbentuk bulat dengan diameter sekitar $20 \mathrm{~cm}$ dan biasanya disajikan sebagai wadah makanan dari Lombok lainnya yaitu pelecing. Selain itu. Menurut Zainuri, dkk (2016), opak singkong dari Lombok Utara ini menempati lima besar produk pangan lokal Lombok dengan nilai penjualan tertinggi di Lombok Utara setelah produk perikanan. Selain itu, permintaan produk pangan lokal di Lombok Utara banyak berasal dari kegiatan wisata yang berkembang di beberapa kawasan pantai sehingga perlu ditingkatkan kualitas produknya baik dari segi nutrisi maupun sensorisnya.

Kelebihan yang dimiliki bahan baku opak singkong menurut Kementrian Pertanian (2016) adalah mengandung kadar gizi makro seperti karbohidrat dan zat gizi mikro yang tinggi, sehingga sejumlah penderita anemia dan kekurangan vitamin $\mathrm{A}$ dan $\mathrm{C}$ ditengah masyarakat yang pangan pokoknya singkong relatif sedikit, kadar glikemik dalam darah rendah, kadar serat pangan larut tinggi, dan berpotensi sebagai probiotik dalam usus. Namun, singkong memiliki kekurangan yaitu kandungan protein sebagai zat gizi makro yang rendah. Menurut Septiatin (2014), kandungan kimia singkong per $100 \mathrm{~g}$ antara lain protein 1,2 g, lemak $0,3 \mathrm{~g}$, karbohidrat $34,7 \mathrm{~g}$, kalsium 33 $\mathrm{mg}$, fosfor $40 \mathrm{mg}$ dan zat besi $0,7 \mathrm{mg}$. Berdasarkan hal tersebut dapat dilihat bahwa gizi opak singkong kurang seimbang dan kurang kandungan protein yang merupakan zat gizi makro yang penting untuk tubuh. Maka dari itu diperlukan tambahan bahan yang mengandung protein tinggi, salah satunya tepung tempe.

Pengolahan tempe menjadi tepung tempe merupakan upaya peningkatan daya simpan tempe dan agar lebih mudah untuk diolah menjadi berbagai macam bentuk. Menurut Murni (2013), tepung tempe memiliki kadar air $4,51 \%$, kadar abu 3,02 \%, kadar protein $46,84 \%$, kadar lemak 22,48\%, kadar serat kasar $5,39 \%$ dan kadar karbohidrat $17,76 \%$. Penambahan tepung tempe pada makanan dapat berdampak baik bagi pertumbuhan.
Berdasarkan penelitian oleh LIPI (2003) melakukan intervensi pada murid SD di daerah Gunung Kidul diperoleh hasil bahwa murid sekolah dasar yang diberikan asupan bahan makanan campuran tepung tempe memiliki berat badan dan tinggi badan yang lebih baik daripada anak yang tidak mendapatkan makanan dari tepung tempe.

Perbaikan kandungan gizi dari opak singkong dari Lombok Utara ini sendiri pernah dilakukan dengan menggunakan ikan ekor kuning dan daun kelor (Wirawan, 2015) dan penambahan tepung daun singkong (Ilham, 2017). Produk sejenis seperti kerupuk opak juga ditambahkan protein dari ikan layur (Salamah, 2008) dan ikan gabus (Setyaji, 2012) yang merupakan protein hewani. Tidak banyak penelitian yang menggunakan protein nabati untuk memperbaiki gizi opak singkong dari Lombok Utara yang gizinya kurang seimbang. Maka dari itu, tujuan dari penelitian ini adalah untuk menentukan konsentrasi tepung tempe yang tepat untuk meningkatkan nutrisi dan mutu sensoris opak singkong dari Lombok Utara.

\section{BAHAN DAN METODE}

\section{Bahan dan Alat}

Bahan-bahan yang digunakan dalam penelitian ini adalah pati singkong (Rose Brand), tempe yang diperoleh dari pasar Narmada, dan bahan tambahan antara lain: garam (Dolpin), kelapa parut, santan dan air. Bahan-bahan kimia yang digunakan memiliki grade P.A atau Pro Analysis seperti aquades, $\mathrm{K}_{2} \mathrm{SO}_{4}, \mathrm{H}_{2} \mathrm{SO}_{4}, \mathrm{CuSO}_{4}, \mathrm{NaOH}, \mathrm{H}_{3} \mathrm{BO}_{3}$ dan petroleum benzene (untuk analisis proksimat).

Alat-alat yang digunakan dalam penelitian ini adalah baskom, parutan, timbangan analitik (Pioneer, USA), alat penjemur berupa pilinan daun kelapa, Teflon (Maxim), blender (Philips, USA), sendok, cetakan egg roll, cabinet dryer, dan ayakan 80 mesh (MBT, Indonesia). Sedangkan alat laboratorium yang digunakan adalah pipet, cawan porselen, buret, statif, lemari asam, desikator, Erlenmeyer, tanur, oven, labu 
Kjedahl, kertas saring, soxhlet, dan alat destilasi.

\section{Metode}

Rancangan percobaan yang digunakan adalah Rancangan Acak Kelompok dan yang dikelompokkan adalah ulangan perlakuan dengan satu faktor yaitu konsentrasi tepung tempe $(P)$, yang terdiri dari 6 taraf yaitu:

$\mathrm{PO}=$ konsentrasi tepung tempe $0 \%$ (kontrol)

$\mathrm{P} 1=$ konsentrasi tepung tempe $5 \%$

$\mathrm{P} 2=$ konsentrasi tepung tempe $10 \%$

P3 $=$ konsentrasi tepung tempe $15 \%$

P4 $=$ konsentrasi tepung tempe $20 \%$

P5 $=$ konsentrasi tepung tempe $25 \%$

Masing-masing perlakuan diulang sebanyak empat kali sehingga diperoleh 24 unit percobaan. Data hasil pengamatan dianalisis dengan analisis keragaman (Analysis of Variance) pada taraf nyata $5 \%$ dengan menggunakan software SPSS. Apabila terdapat perbedaan nyata, maka data diuji lanjut dengan uji polinomial ortogonal untuk uji kadar zat gizi dan uji Beda Nyata Jujur untuk uji sensoris pada taraf nyata 5\% (Sastrosupadi, 2000).

\section{Pelaksanaan Penelitian \\ Pembuatan Tepung Tempe}

Tempe diiris berbentuk segi empat dengan ukuran $5 \mathrm{~cm} \times 5 \mathrm{~cm} \times 0,5 \mathrm{~cm}$ kemudian dikukus selama 10 menit dengan suhu $100^{\circ} \mathrm{C}$. Setelah dikukus dilakukan penirisan dan dikeringkan dengan cabinet dryer selama 4 jam dengan suhu $60^{\circ} \mathrm{C}$. Setelah kering, tempe digiling menjadi partikel-partikel tepung dan diayak dengan ukuran ayakan 80 mesh.

\section{Pembuatan Opak Singkong}

Pembuatan opak membutuhkan binder sebagai perekat adonan. Proses pembuatan binder dilakukan dengan cara mencampurkan tepung tapioka dengan air. Rasio tepung dan air adalah 1:12 kemudian dimasak hingga tergelatinisasi dengan suhu $60-65^{\circ} \mathrm{C}$ selama 1 menit. Setelah itu dilakukan pencampuran bahan-bahan diantaranya santan, kelapa parut, tepung tapioka, binder, garam dan tepung tempe dengan berbagai konsentrasi sesuai dengan perlakuan. Kemudian dilakukan pencetakan adonan dengan menggunakan teflon. Adonan cair ditimbang seberat $25 \mathrm{~g}$ dan ditung pada teflon kemudian dipanaskan selama 1 menit pada suhu $\pm 128^{\circ} \mathrm{C}-130^{\circ} \mathrm{C}$. Adonan yang telah dicetak kemudian dikeringkan menggunakan sinar matahari dengan suhu $\pm 45^{\circ} \mathrm{C}$ selama 4 jam atau sampai kering dengan alas penjemur berupa anyaman daun kelapa. Opak yang telah kering dipanggang dengan menggunakan cetakan egg roll dengan suhu $170^{\circ} \mathrm{C}$ selama 2 menit sambil dibolak-balik agar matang merata pada kedua sisinya.

\section{HASIL DAN PEMBAHASAN}

\section{Kadar Protein}

Protein merupakan senyawa organik kompleks yang mengandung asam amino yang terikat satu sama lain melalui ikatan peptide. Protein mengandung atom karbon, oksigen, nitrogen dan sulfur. Protein merupaka sumber gizi utama yaitu sebagai sumber asam amino esensial. Protein merupakan komponen pangan yang banyak terdapat pada tanaman dan hewan sebagai penyusun sel. Kandungan protein dalam bahan pangan bevariasi, baik dalam jumlah maupun jenisnya (Kusnandar, 2010). Protein adalah salah satu makronutrien yang memiliki peranan penting dalam pembentukan biomolekul. Protein menentukan ukuran dan struktur sel, komponen utama dari enzim yaitu biokatalisator sebagai reaksi metabolisme dalam tubuh (Cakrawati dan Mustika,2014).

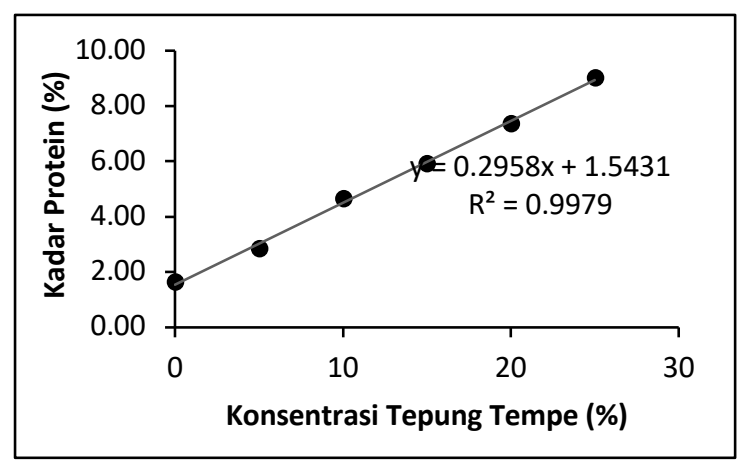

Gambar 1. Grafik Pengaruh Konsentrasi Tepung Tempe terhadap Kadar Protein Opak Singkong Dari Lombok Utara 
Gambar 1 menunjukkan nilai kadar protein yang terus meningkat dari perlakuan $\mathrm{PO}$ hingga P5. Hal ini disebabkan oleh tingginya kadar protein tepung tempe yang ditambahakan yaitu sebesar $36,81 \%$. Hal tersebut sejalan dengan pendapat Murni (2014) yang menyatakan bahwa semakin meningkatnya penambahan tepung tempe maka kadar protein produk akan semakin naik dan hal tersebut disebabkan oleh tepung tempe yang memiliki kadar protein yang lebih tinggi dari bahan baku.

\section{Kadar Air}

Air merupakan salah satu zat penyusun pangan. Pangan seluruhnya mengandung air, namun dengan jumlah yang berbeda-beda. Air dalam pangan berperan dalam memengaruhi tingkat kesegaran, stabilitas, keawetan dan kemudahan terjadinya reaksi-reaksi kimia, aktivitas enzim serta pertumbuhan mikroba. Air dalam pangan berada dalam keadaan bebas, terserap dalam jaringan pangan ataupun terikat secara kimia pada senyawa lain. Kadar air pada pangan menyatakan jumlah absolut air dalam pangan sebagai komponen pangan (Kusnandar, 2010).

Perlakuan penambahan konsentrasi tepung tempe memiliki pengaruh yang tidak berbeda nyata terhadap kadar air opak singkong dari Lombok Utara. Hasil kadar air cenderung bervariasi dalam rentang 3,9\% hingga 5,1 \%. Hal tersebut diduga karena faktor metode pengolahannya khususnya pada metode pengeringan dengan mengunakan sinar matahari. Hal ini berdasarkan penelitian Nendissa (2012) dimana proses pengolahan kerupuk dengan pengeringan sinar matahari dapat mempengaruhi kadar air. Menurut Fellows (2000), kelemahan yang dimiliki metode pengeringan dengan sinar matahari adalah lemahnya kontrol terhadap kondisi pengeringan dan tergantung oleh cuaca, sehingga dihasilkan produk yang memiliki kualitas lebih rendah dan variabilitas yang lebih besar.

\section{Kadar Abu}

Abu merupakan residu anorganik dari proses pembakaran atau oksidasi komponen organik bahan pangan. Kadar abu dari suatu bahan menunjukkan kandungan mineral yang terdapat dalam bahan tersebut, kemurnian, serta kebersihan suatu bahan yang dihasilkan (Andarwulan, dkk 2011).

Perlakuan penambahan konsentrasi tepung tempe memiliki pengaruh yang tidak berbeda nyata terhadap kadar abu opak singkong dari Lombok Utara. Hasil kadar abu bervariasi dalam rentang $2,43 \%$ hingga $2,70 \%$ yang tidak jauh beda antara satu dengan yang lainnya. Hal tersebut dikarenakan penambahan tepung tempe yang digunakan pada setiap perlakuan rentangnya tidak terlalu jauh berbeda. Hasil analisa kadar abu tepung tempe menunjukkan bahwa tepung tempe yang digunakan mengandung abu juga sangat rendah yaitu sebesar 1,83\%. Menurut Mustakim (2016), tinggi rendahnya kadar abu dipengaruhi oleh perbedaan kandungan mineral yang terdapat pada bahan baku.

\section{Kadar Lemak}

Lemak adalah senyawa ester non-polar yang tidak larut dalam air, yang dihasilkan oleh tanaman dan hewan. Lemak disusun oleh atom utama karbon $(\mathrm{C})$, hydrogen $(\mathrm{H})$ dan oksigen (O), tetapi mengandung jumlah hydrogen lebih banyak dan oksigen lebih sedikit dibandingkan karbohidrat (Kusnandar, 2010).

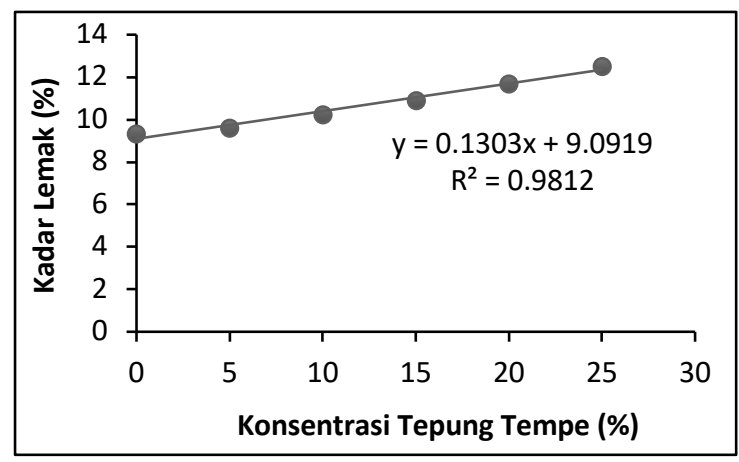

Gambar 2. Grafik Pengaruh Konsentrasi Tepung Tempe terhadap Kadar Lemak Opak Singkong Dari Lombok Utara

Gambar 2 menunjukkan nilai kadar lemak yang terus meningkat dimana pada perlakuan tanpa penambahan atau P0 diperoleh nilai kadar lemak terendah sebesar 
9,33\% dan nilai kadar lemak tertinggi diperoleh pada perlakuan penambahan tepung tempe sebanyak $25 \%$ sebesar $12,51 \%$. Hal ini disebabkan oleh tingginya kadar lemak tepung tempe yang ditambahakan yaitu sebesar $26,47 \%$. Hal tersebut sejalan dengan pendapat Murni (2014) yang menyatakan bahwa semakin meningkatnya penambahan tepung tempe maka kadar lemak produk akan semakin naik dan hal tersebut disebabkan oleh tepung tempe yang memiliki kadar lemak yang lebih tinggi dari bahan baku yaitu 26,4702 .

\section{Kadar Karbohidrat by difference}

Karbohidrat adalah senyawa organik yang terdapat di alam yang jumlahnya paling banyak dan bervariasi dibandingkan dengan senyawa organik lainnya. Senyawa ini disusun oleh tiga jenis atom, yaitu karbon, hidrogen dan oksigen dengan rumus umum $\mathrm{C}_{x}\left(\mathrm{H}_{2} \mathrm{O}\right)_{y}$ yang menunjukkan hidrat dari karbon. Sumber utama karbohidrat di alam, di antaranya adalah serealia, biji-bijian, umbi-umbian, buahbuahan, sayur-sayuran, susu dan sebagainya. Karbohidrat berfungsi sebagai cadangan energi dalam tubuh manusia dalam bentuk glikogen dan sebagai sumber serat yang diperlukan oleh tubuh manusia (Kusnandar, 2010).

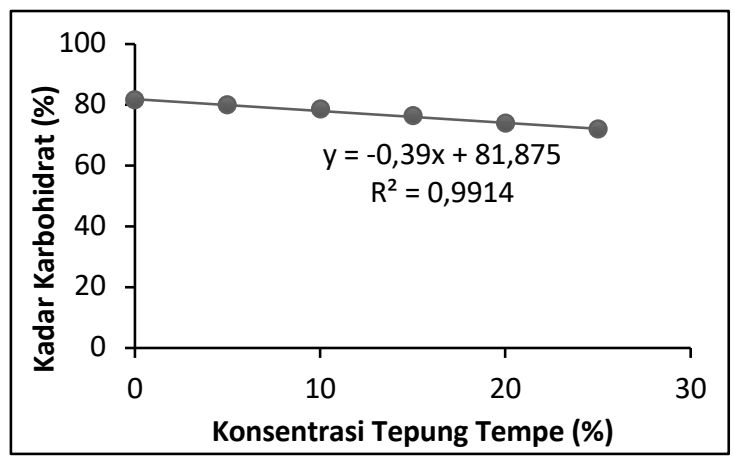

Gambar 3. Grafik Pengaruh Konsentrasi Tepung Tempe terhadap Kadar Karbohidrat Opak Singkong Dari Lombok Utara

Gambar 3 menunjukkan nilai kadar karbohidrat yang terus menurun dimana pada perlakuan tanpa penambahan atau PO diperoleh nilai kadar karbohidrat tertinggi sebesar $81,58 \%$ dan nilai kadar karbohidrat terendah diperoleh pada perlakuan penambahan tepung tempe sebanyak $25 \%$ sebesar $71,84 \%$. Hal tersebut disebabkan oleh kandungan protein tepung tempe lebih besar dari karbohidrat dan kandungan lemak yang cukup tinggi sehingga akan menurunkan kadar karbohidrat opak singkong dari Lombok Utara. Hal ini sejalan dengan pendapat yang dikemukaan oleh Sugito dan Hayati (2006), dimana kadar karbohidrat dipengaruhi oleh kadar senyawa lain, semakin tinggi kadar senyawa lain maka kadar karbohidrat akan semakin rendah.

\section{Total Kalori}

Energi adalah zat yang diperlukan untuk makhluk hidup untuk mempertahankan hidup, menunjang pertumbuhan dan melakukan aktivitas fisik. Satuan energi dinyatakan dalam unit panas atau kilokalori, satu kilokalori adalah jumlah panas yang diperlukan untuk menaikkan suhu air $1 \mathrm{~kg}$ sebanyak $1^{\circ} \mathrm{C}$. Kandungan energi pada bahan makanan dapat dihitung dengan memakai alat bomb calorie meter atau dengan cara tidak langsung, berdasarkan kandungan karbohidrat, protein dan lemak (Cakrawati dan Mustika, 2014).

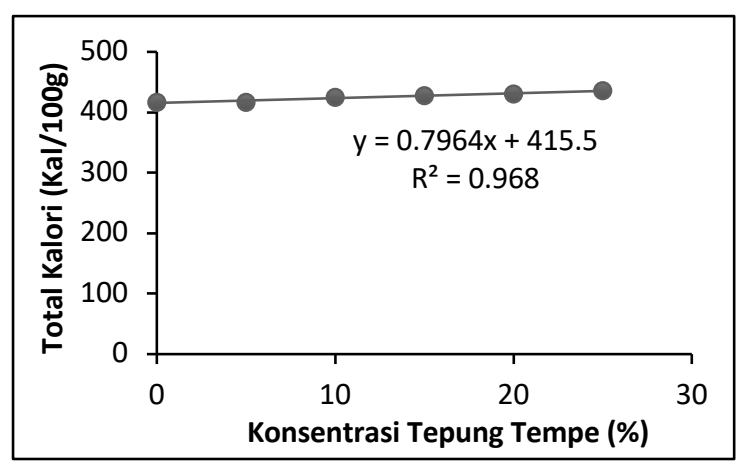

Gambar 4. Grafik Pengaruh Konsentrasi Tepung Tempe terhadap Total Kalori Opak Singkong Dari Lombok Utara

Gambar 4 menunjukkan nilai total kalori yang terus meningkat dimana pada perlakuan tanpa penambahan atau P0 diperoleh nilai total kalori terendah sebesar 416,82 Kal/100 g dan nilai total kalori tertinggi diperoleh pada perlakuan penambahan tepung tempe sebanyak $25 \%$ sebesar $436,15 \mathrm{Kal} / 100 \mathrm{~g}$. Hal ini disebabkan oleh jumlah kandungan bahanbahan yang digunakan untuk pembuatan opak. Hal ini berdasarkan pendapat Muchtadi (2009) dalam Anandito, dkk (2016), yang menyatakan 
bahwa energi yang terkandung dalam makanan tergantung dari jumlah zat gizi yang terkandung dalam makanan. Pembuatan opak singkong ini mengunakan bahan-bahan yaitu tepung tapioka, tepung tempe, santan, air dan garam yang masing-masing menyumbangkan energi dalam produk opak singkong dari Lombok Utara. Tepung tapioka memiliki kadar karbohidrat yang tinggi, tepung tempe mengandung protein dan lemak yang tinggi serta santan juga mengandung lemak yang tinggi. Kenaikan total kalori disebabkan oleh naiknya kadar zat gizi lain yaitu protein dan lemak akibat penambahan tepung tempe.

\section{Analisis Keutuhan}

Keutuhan merupakan salah satu parameter dalam penentuan mutu kerupuk. Keutuhan kerupuk dapat dilihat dengan membandingakan berat kerupuk keseluruhan yang dikurangi dengan berat kerupuk yang tidak utuh dengan berat keseluruhan kerupuk.

Konsentrasi tepung tempe memiliki pengaruh yang tidak berbeda nyata terhadap keutuhan opak singkong dari Lombok utara. Nilai keutuhan yang diperoleh bersifat konstan. Hal tersebut diduga disebabkan karena penggunaan tepung tapioka dari setiap opak singkong sama dan penambahan tepung tempe tidak memberi pengaruh yang berbeda nyata terhadap keutuhan opak singkong dari Lombok Utara. Menurut Arifin, dkk (2017) keutuhan mie dipengaruhi oleh kandungan amilosa dan amilopektin. Jika kandungan amilopektin lebih tinggi pati akan bersifat basah, sedikit menyerap air dan lengket. Amilopektin juga membentuk sifat elastis sehingga mi tidak mudah putus atau patah. Tepung tapioka mengandung amilopektin lebih banyak daripada amilosa yaitu berturut-turut $82,61 \%$ dan 17,39\% (Rohman, 2007 dalam Kurniawati, 2017). Oleh karena itu nilai keutuhan opak singkong hampir $100 \%$ untuk setiap perlakuan.

\section{Sensoris Tekstur}

Tekstur merupakan hal yang penting dalam makanan ringan atau camilan seperti kerupuk. Tekstur menjadi salah satu tolak ukur kesukaan masyarakat dari produk kerupuk
(Irmayanti, dkk, 2017). Apabila pada atribut tekstur buruk, maka akan menimbulkan efek negatif pada tingkat kesukaan konsumen (Lawless, 2010).

Hasil uji scoring dan hedonic dapat dilihat pada Gambar 5. Dari hasil analisis ragam menunjukkan bahwa baik pada uji hedonik maupun scoring pada opak singkong dari Lombok Utara tidak berbeda nyata antara perlakuan P0 hingga P5. Hal tersebut menunjukkan bahwa penambahan tepung tempe hingga $25 \%$ tidak mempengaruhi tingkat kesukaan dan penilaian panelis pada atribut tekstur opak singkong dari Lombok Utara. Hal tersebut diduga karena penggunaan jumlah tepung tapioka yang sama pada setiap perlakuan dimana menurut Irmayanti (2017), tekstur dipengaruhi oleh adanya kandungan pati serta ketebalan dari kerupuk tersebut.

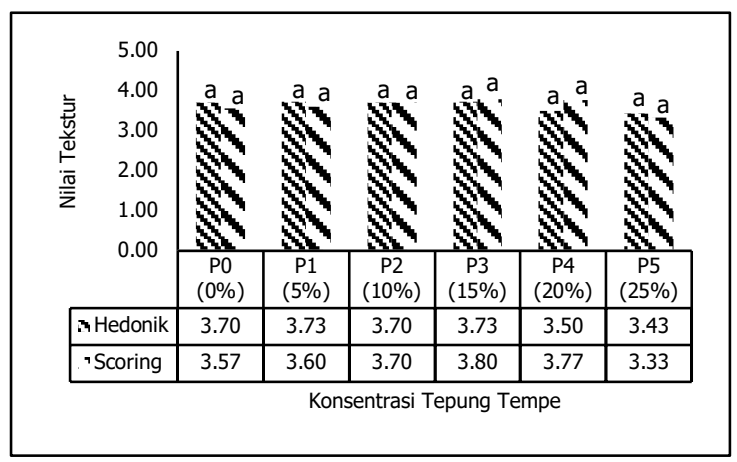

Gambar 5. Diagram Pengaruh Konsentrasi Tepung Tempe terhadap Mutu Sensoris Tekstur Opak Singkong Dari Lombok Utara

\section{Sensoris Warna}

Warna dari suatu objek dipengaruhi oleh tiga hal yaitu komposisi fisik dan kimianya, komposisi spektrum cahaya yang menyinarinya dan sensitifitas spectrum dari mata panelis. Pada produk makanan, konsumen sering menilai kualitas dari produk dengan melihat warnanya sehingga warna menjadi atribut yang penting untuk menarik konsumen (Lawless, 2010).

Perlakuan penambahan konsentrasi tepung tempe memiliki pengaruh yang berbeda nyata terhadap warna opak singkong dari Lombok Utara baik pada uji hedonik maupun scoring. Berdasarkan hasil uji hedonik untuk 
atribut warna opak singkong Dari Lombok Utara yang dapat dilihat pada Gambar 6, semakin tinggi konsentrasi tepung tempe maka tingkat kesukaan cenderung menurun. Hal ini diduga karena warna kuning dari tepung tempe menurunkan kesukaan panelis terhadap warna opak karena berbeda dengan warna opak tanpa penambahan.

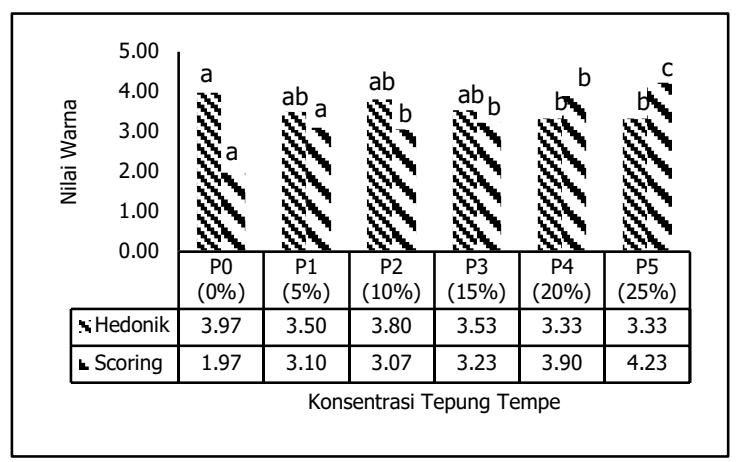

Gambar 6. Diagram Pengaruh Konsentrasi Tepung Tempe terhadap Mutu Sensoris Warna Opak Singkong Dari Lombok Utara

Berdasarkan hasil uji scoring, semakin tinggi konsentrasi penambahan tepung tempe maka akan semakin kuning warna opak. Hal ini disebabkan oleh tepung tempe yang berwarna kekuningan sehingga semakin banyak penambahannya maka akan menyebabkan warna kuning pada opak. Pendapat tersebut sejalan dengan pendapat Murni (2013) yang menyatakan bahwa semakin banyak persentase penggunaan tepung tempe maka tingkatan warna kue nagasari dari putih akan menjadi coklat muda sedangkan kue kelepon yang berwarna hijau akan semakin pudar.

\section{Sensoris Aroma}

Aroma merupakan salah satu faktor yang mempengaruhi kualitas makanan. Aroma adalah reaksi dari makanan yang akan mempengaruhi konsumen sebelum konsumen menikmati makanan, konsumen dapat mencium aroma makanan tersebut (Fiani dan Japarianto, 2012). Perlakuan penambahan konsentrasi tepung tempe memiliki pengaruh yang tidak berbeda nyata terhadap aroma opak singkong dari Lombok Utara pada uji hedonik dan memberikan pengaruh yang berbeda nyata pada uji scoring.

Gambar 7 menunjukkan hasil uji scoring dan hedonik atribut aroma Opak Singkong dari Lombok Utara. Berdasarkan hasil uji scoring didapati hasil bahwa semakin tinggi konsentrasi penambahan tepung tempe maka opak akan beraroma tempe. Opak singkong mulai agak beraroma tempe pada perlakuan P2 sampai P5. Menurut Murni (2013) tepung tempe memiliki aroma dari langu sehingga semakin banyak tepung tempe yang ditambahkan akan mempengaruhi aroma produk. Aroma dari ini berasal dari kapang Rhizopus oligosporus yang mempengaruhi aktivitas protease dan lipase yang tinggi, amilolitiknya rendah dan menghasilkan antioksidan (Koswara, 1995 dalam Murni 2013). Sedangkan hasil uji hedonik menunjukkan bahwa tingkat kesukaan panelis tidak berbeda nyata antara perlakuan P0 hingga P5 dan berada pada rentang agak suka. Hal tersebut menunjukkan bahwa penambahan tepung tempe tidak mempengaruhi kesukaan panelis terhadap atribut aroma opak singkong dari Lombok Utara.

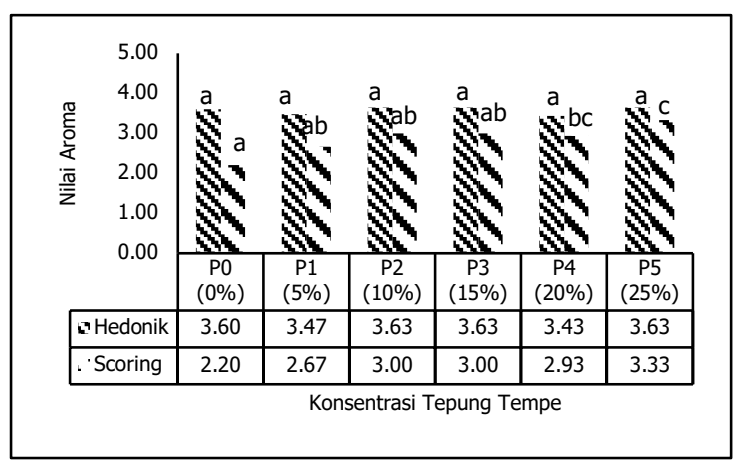

Gambar 7. Diagram Pengaruh Konsentrasi Tepung Tempe terhadap Mutu Sensoris Aroma Opak Singkong Dari Lombok Utara

\section{Sensoris Rasa}

Rasa merupakan respon lidah terhadap rangsangan yang diberikan oleh suatu makanan yang merupakan salah satu faktor penting yang dapat berpengaruh terhadap konsumen pada suatu produk makanan dimana rasa menentukan keputusan akhir konsumen untuk menerima atau menolak suatu makanan 
(Gunawan, dkk, 2012). Berdasarkan analisis keragaman (ANOVA), menunjukkan bahwa perlakuan penambahan konsentrasi tepung tempe memiliki pengaruh yang berbeda nyata terhadap rasa opak singkong dari Lombok Utara pada uji hedonik maupun pada uji scoring.

Hasil uji scoring dan hedonik dari atribut Rasa Opak singkong khas Lombok Utara dapat dilihat pada Gambar 8. Berdasarkan hasil uji tingkat kesukaan atau hedonik, tingkat kesukaan panelis meningkat pada perlakuan $\mathrm{P} 3$ dan menurun pada P4 dan P5. Hal ini disebabkan karena tepung tempe dapat meningkatkan rasa produk dan juga menurunkan kesukaan apabila ditambahkan dalam jumlah banyak. Hal ini berdasarkan penelitian Murni (2013) dimana penggunaan tepung tempe yang mengandung protein dan lemak yang tinggi sehingga berpengaruh terhadap rasa lumpia, selain itu menurut Winarno (1997) dalam Murni (2013) penyebab terjadinya rasa gurih dari suatu produk ditentukan oleh besarnya kandungan protein dan lemaknya. Namun, menurut Ginting (2013) menyatakan bahwa semakin banyak penambahan tepung tempe menyebabkan nilai organoleptik rasa menurun karena adanya senyawa anti gizi dan senyawa penyebab off flavor pada bahan mentah pembuatan tepung tempe yaitu kacang kedelai. Off flavor pada produk tersebut yaitu adanya rasa pahit yang disebabkan oleh adanya senyawa glikosida, saponin dan estrogen dalam biji kedelai.

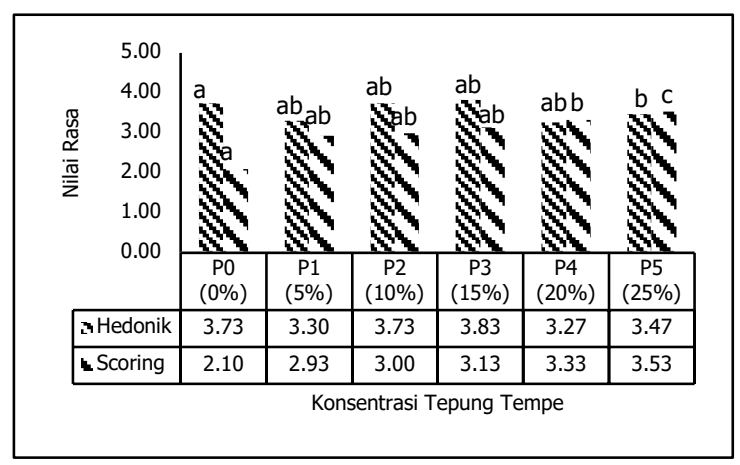

Gambar 8. Diagram Pengaruh Konsentrasi Tepung Tempe terhadap Mutu Sensoris Rasa Opak Singkong Dari Lombok Utara
Hasil uji scoring semakin tinggi konsentrasi penambahan tepung tempe maka opak akan semakin berasa tempe. Hal ini disebabkan karena tepung tempe memiliki rasa dari tempe yang akan mempengaruhi rasa dari opak. Hal tersebut sesuai dengan pendapat Mustakim (2016) dimana semakin banyak tepung tempe yang digunakan akan meghasilkan kerupuk dengan rasa tempe yang lebih dominan dan menutupi rasa jagung.

\section{KESIMPULAN}

Berdasarkan hasil analisis dan pembahasan dapat disimpulkan bahwa konsentrasi tepung tempe pada opak singkong dari Lombok Utara memberikan pengaruh yang berbeda nyata terhadap parameter uji nutrisi yaitu kadar protein, kadar lemak, kadar karbohidrat dan total kalori. Semakin tinggi konsentrasi tepung tempe maka akan semakin tinggi kadar protein, lemak dan total kalori dari Opak singkong dari Lombok Utara. Selain itu, konsentrasi tepung tempe juga memberikan pengaruh yang berbeda nyata terhadap parameter mutu sensoris pada atribut warna dan rasa secara hedonik serta atribut warna, aroma dan rasa secara scoring. Berdasarkan hasil uji sensoris penambahan tepung tempe sebanyak $15 \%$ adalah perlakuan terbaik yang cita rasanya agak disukai oleh panelis dengan kadar protein 5,92\%; kadar air 4,10\%; kadar abu 2,60\%; kadar lemak 10,89\%; kadar karbohidrat 76,46\%; total kalori 427,63 $\mathrm{Kal} / 100 \mathrm{~g}$; berwarna putih kekuningan; bertekstur agak renyah; agak beraroma tempe dan agak berasa tempe.

\section{DAFTAR PUSTAKA}

Anandito, R.B.K., Siswanti dan D.T. Kusumo. 2016. Kajian Karakteristik Sensoris dan Kimia Bubur Instan Berbasis Tepung Milet Putih dan Tepung Kacang Merah. Jurnal Teknologi Hasil Pertanian 9(1): 17-23.

https://jurnal.uns.ac.id/ilmupangan/artic le/view/12848 [Diakses pada 27 Mei 2018]

Andarwulan, N., F. Kusnandar, dan D. Herawati. 2011. Analisis Pangan. Dian Rakyat. Jakarta. 
Versi Online:

http://www.profood.unram.ac.id/index.php/profood e-ISSN: 2443-3446

Arifin, T., A. Ali dan F. Hamzah. 2017. Pembuatan Mi Instan dari Tepung Jagung Lokal Riau Dengan Penambahan Brokoli. JOM FAPERTA UR 4(1): 1-14. https://www.neliti.com/search?q=Pemb uatan+Mi+Instan+Dari+Tepung+Jagun g+Lokal+Riau+Dengan+Penambahan+ Brokoli [Diakses pada 25 Mei 2018]

Badan Pusat Statistik. 2014. Luas Panen, Produksi Dan Produktivitas Ubi Kayu Provinsi Nusa Tenggara Barat. Badan Pusat Statistik Provinsi NTB, Mataram. https://ntb.bps.go.id/linkTableDinamis/v iew/id/105. [Diakses tanggal 19 Mei 2018]

Cakrawati, D dan N.H. Mustika. 2011. Bahan Pangan, Gizi dan Kesehatan. Alfabeta. Bandung.

Fellows, P. 2000. Food Processing Technology $2^{\text {nd }}$ Edition. CRC Press. Boca Raton, USA. http://bookfi.net/book/1176063

[Diakses pada 4 Desember 2018]

Fiani, M dan E. Japarianto. 2012. Analisa Pengaruh Food Quality dan Brand Image terhadap Keputusan Pembelian Roti Kecik Toko Roti Ganep's di Kota Solo. Jurnal Manajemen Pemasaran 1(1): 1-6. http://publication.petra.ac.id/index.php/ manajemenpemasaran/article/view/72 [Diakses pada 1 Januari 2019]

Ginting, P., S. Ginting dan L.N. Limbong. 2013. Pengaruh Perbandingan Tepung Talas Dengan Tepung Tempe dan Konsentrasi Baking Soda Terhadap Mutu Kerupuk Talas. Jurnal Rekayasa Pangan dan Pertanian 1(4): 29-38. http://repository.usu.ac.id/handle/1234 56789/44055 [Diakses pada 2 Jauari 2019]

Gunawan, R., Edison dan Suparmi. 2012. Efek Rumput Laut Pada Penerimaan Konsumen terhadap Mi Kering. Artikel. Fakultas Perikanan dan Kelautan, Universitas Riau. Riau. https://repository.unri.ac.id/bitstream/h andle/12... [Diakses pada Januari 2019]

Ilham, L.F. 2017. Pengaruh Penambahan Konsentrasi Tepung Daun Singkong Terhadap Sifat Kimia dan Organoleptik Opak Singkong Dari Lombok Utara. Skripsi. Fakultas Teknologi Pangan dan Agroindustri. Universitas Mataram. Mataram.
Pro Food (Jurnal IImu dan Teknologi Pangan)

Vol 5 No. 2 November 2019

ISSN: 2443-1095

Irmayanti, H. Syam dan Jamaludin. 2017. Perubahan Tekstur Kerupuk Berpati Akibat Suhu dan Lama Penyangraian. Jurnal Pendidikan Teknologi Pertanian 3(1):165-174.

https://ojs.unm.ac.id/ptp/article... [ Diakses pada 2 Januari 2019]

Kementrian Pertanian. 2016. Outlook Komoditas Pertanian Sub Sektor Tanaman Pangan: Ubi Kayu. Kementrian Pertanian. Jakarta. http://epublikasi.pertanian.go.id/arsipoutlook/... [Diakses pada Juni 2018]

Kurniawati, I. 2017. Peningkatan Mutu Jajanan Tradisional Opak dari Lombok. Skripsi. Fakultas Teknologi Pangan dan Agroindustri. Universitas Mataram. Mataram.

Kusnandar, F. 2010. Kimia Pangan: Komponen Makro. Dian Rakyat. Jakarta.

Lawless, H.T. and H. Heymann. 2010. Sensory Evaluation of Food: Principles and Practices. Springer. New York, USA. http://bookfi.net/book/1467378

[Diakses pada 2 November 2018]

Lembaga Ilmu Pengetahuan Indonesia. 2007. LIPI Kembangkan Tepung Tempe. http://lipi.go.id/berita/lipi-kembangkantepung-tempe/204. [Diakses 18 Mei 2018]

Murni, M. 2013. Kajian Penambahan Tepung Tempe Pada Pembuatan Kue Basah terhadap Daya Terima Konsumen. Artikel REKAPANGAN. Universitas Veteran, Surabaya.

http://ejournal.upnjatim.ac.id/index.php L... [ Diakses pada 18 Mei 2018]

Murni, M. 2014. Pengaruh Penambahan Tepung Tempe Terhadap Kualitas dan Citarasa Naget Ayam. Berita Litbang Industri 3(2):

117-123.

http://ejournal.kemenperin.go.id/blisby/ issue/... [Diakses pada 2 Januari 2019]

Mustakim, Yusmarini dan N. Herawati. 2016. Pemanfaatan Tepung Jagung dan Tepung Tempe Dalam Pembuatan Kerupuk. Jom Faperta 3(1):1-15. https://www.neliti.com/search?q=Pema nfaatan+Tepung+Jagung+dan+Tepung +Tempe+Dalam+Pembuatan+Kerupuk [Diakses pada 2 Januari 2019] 
Versi Online:

http://www.profood.unram.ac.id/index.php/profood e-ISSN: 2443-3446

Nendissa, S.J. 2012. Pemanfaatan Tepung Sagu Molat dan Udang Sebagai Bahan Campuran Pembuatan Kerupuk. Jurnal Ekologi dan Sains 1(1):53-64. https://ejournal.unpatti.ac.id/ppr itemin fo Ink.php?id=414 [Diakses pada 1 Januari 2019]

Salamah, E., M.R. Susanti, S. Purwaningsih. 2008. Diversifikasi Produk Kerupuk Opak dengan Penambahan Daging Ikan Layur (Trichiurus sp). Buletin Teknologi Hasil Perikanan 11(1): 53-64. https://repository.ipb.ac.id/handle/1234 $\underline{56789 / 29548}$ [Diakses pada 8 Juni 2018]

Sastrosupadi, A. 2000. Rancangan Percobaan Praktis Bidang Pertanian. Kanisius. Yogyakarta.

https://books.google.co.id/books/...[Dia kses pada 29 Oktober 2018]

Septiatin, A. 2014. Apotek Hidup dari Sayuran dan Tanaman Pangan. CV.Yrama Widya. Bandung.

Setyaji, H., V. Suwita, dan A. Rahimsyah. 2012. Sifat Kimia dan Fisika Kerupuk Opak dengan Penambahan Daging Ikan Gabus (Ophiocephalus striatus). Jurnal Penelitian Universitas Jambi Seri Sains 14(1): 17-22. $\quad$ https://onlinejournal.unja.ac.id/index.php/sains/articl e/view/517 [Diakses pada 8 Juni 2018]

Sugito dan A. Hayati. 2006. Penambahan Daging Ikan Gabus Dan Aplikasi Pembekuan Pada Pembuatan Pempek Gluten. Jurnal IImu-IImu Pertanian Indonesia $\quad 8(2)$ : $147-151$. http://repository.unib.ac.id/65/1/147JIP I-2006.pdf [Diakses pada 2 Januari 2019]

Wirawan, S., F. Luthfiyah, Mardiansyah, dan Ristrini. 2015. Intervensi Pemberian Makanan Tradisional Opak-Opak dengan Pengayaan Ikan Ekor Kuning dan Serbuk Daun Kelor Sebagai Alternatif Makanan Selingan Bergizi Untuk Ibu Hamil KEK Di Kabupaten Lombok Utara, NTB. Buletin Penelitian Sistem Kesehatan 18(2): 203210.

https://media.neliti.com/media/...pdf [Diakses pada 1 Juni 2018]

Zainuri, A. Zaini, W. Werdiningsih, dan T. Sjah, 2016. Keragaman Pangan Lokal di Pulau Lombok Untuk Menunjang Pengembangan Pariwisata. Jurnal
Pro Food (Jurnal IImu dan Teknologi Pangan)

Vol 5 No. 2 November 2019

ISSN: 2443-1095

Agritech 36(2):206-2018. https://jurnal.ugm.ac.id/agritech/article/ view... [Diakses pada 18 Mei 2018]

Zulhaedar, F., dan M. Nazam. 2016. Karakteristik Lahan dan Potensi Pengembangan Ubi Kayu di Lombok Utara, Nusa Tenggara Barat. Prosiding Seminar Hasil Penelitian Tanaman Aneka Kacang dan Umbi. Hal: 508-516. http://balitkabi.litbang.pertanian.go.id/ wp-cont...pdf [Diakses pada 18 Mei 2018] 